and Strategies for Future Planning, edited by Peter Gellatly (Haworth, 1982, \$45). This book examines major working serials control systems in the United States and Canada, describes their operations, and discusses their successes and shortcomings.

- The Changing Concept of Information: An Introductory Analysis, by Kevin J. McGarry (Clive Bingley, 1981, \$19.50), evaluates the impact of the various technologies for recording and disseminating information, the opportunities which new technologies open up, the constraints which they impose, and the way that society adapts itself to the means of communication available.

-Richard M. Neustadt, in The Birth of Electronic Publishing (Knowledge Industry, 1982, \$32.95), collects the whole of current U.S. communications laws and regulations and analyzes their probable effect on the new electronic technology.

- The authors in Research in the Age of the Steady-State University, edited by Don I. Phillips and Benjamin S.P. Shen (Westview, 1982, $\$ 16.50)$, point to the need for a strong cooperative relationship between research and education. Representatives of the scientific, educational, and government sectors look at the problems and prospects facing U.S. research and university education, presenting the perspectives of their own institutional biases and turning also to the experiences of Canada and Western Europe.

-Tomorrow's Universities: A World Wide Look at Educational Change, compiled by W. Werner Prange, David Jowett, and Barbara Fogel (Westview, 1982, \$20), provides an important contribution to higher education and to the understanding of university innovations throughout the world. The authors of this volume have provided a muchneeded, authoritative, and comprehensive account of the practical as well as the philosophical reasons for global university innovation at the beginning of the 1980s.

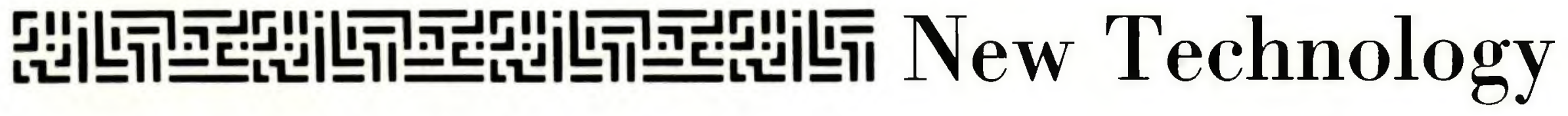

-CL SYSTEMS, INC., Newtonville, Massachusetts, has introduced a Model P-300 Report Printer for larger libraries which have a high volume requirement for printing management reports and patron notices with the LIBS 100 System. The printer features a 96-character upper and lower case character set and prints at a speed of 240 lines per minute. Originally manufactured by Printronix, Inc., the Model P-300 was selected by CLSI because of its high quality, high reliability, and proven performance in many other data processing applications. The printer has already been installed at the California State University Library, Northridge, and the Herbert H. Lehman College Library, Bronx, New York. Contact CLSI, 81 Norwood Avenue, Newtonville, MA 02160; (617) 965-6310.

- COMMTEX INTERNATIONAL, the primary American exposition for communications and information technologies, will be held in the New Orleans Superdome on January $21-24$ in conjunction with the 1983 National Audio-Visual Association Convention. The exposition is cosponsored by NAVA and the Association for Educational Communications and Technology and replaces their individual annual exhibits. This first annual show will feature the newest equipment and materials/ software of more than 400 major manufacturers and producers of A-V/video/microcomputer products. The NAVA Covention will feature technology updates, funding and legislative outlooks, and special events. AECT will also hold its annual convention at the same time and will include over 300 sessions, workshops and seminars on such topics as telecommunications, media program management, microcomputer applications, and training program design. For more information on COMMTEX, contact NAVA, 3150 Spring Street, Fairfax, VA 22031; for further details on the AECT Convention, contact AECT, 1126 16th Street, N.W., Washington, DC 20036.

- DIALOG INFOrmation Services, InC., has added nine databases to its retrieval system: Telegen, produced by the Environment Information Center (biotechnology and genetic engineering); Books in Print, from the R.R. Bowker Co. (includes forthcoming books); Laborlaw, produced by the Bureau of National Affairs (labor relations, fair

\section{Alternate Life-Styles}

Jeff Selth, reference librarian at the University of California, Riverside, has begun a project which should result in a directory of special collections in libraries, archives, and other institutions relating to the history and practice of nudism, the free sex movement, group marriage, or communes featuring any of these lifestyles. He would like to contact as many libraries, associations, or individuals that possess any material, published or unpublished, which would be useful to researchers interested in the history of alternative life-styles, especially in the United States and Canada in recent decades. Typed or handwritten documents and newspaper articles are considered especially valuable.

Readers with any information should contact Jeff Selth, The Library, University of California, Riverside, CA 92517. 
employment, wages and hours, occupational safety and health); Paperchem, produced by the Institute of Paper Chemistry (paper industry); Electronic Yellow Pages-Construction Directory, produced by Market Data Retrieval (contractors and construction agencies); Waternet, by the American Water Works Association; BLS Employment, Hours, and Earnings, from the files of the U.S. Bureau of Labor Statistics; Chemsis $82+$, from Chemical Abstracts (chemical substance records in CA Search); and Chemzero (chemical substance records not found in CA Search). For further information, contact DIALOG Information Services, Inc., 3460 Hillview Ave., Palo Alto, CA 94304; (800) 227-1927, or in California (800) 9825838.

-EBSCO Subscription SERvices has developed EBSCONET, an online serials system designed to adapt to varying library needs. Its two subsystems are Online Subscription Services for claims, orders, and price information, and the Serials Control System for check-in, binding, full record and reference display. An accounting function is planned for the near future. For more information, contact EBSCONET Staff, P.O. Box 1943, Birmingham, AL. 35203; (205) 252-1212.

-A new book by Howard FosDick on computer applications in libraries is now available. Struc-

\section{ACRL Fellowships}

Remember that December 1, 1982, is the deadline for applications for the two new ACRL fellowships announced in C\&RL News, October, p. 317. There are no application forms for the ACRL Doctoral Dissertation Award or the Lazerow Award. Interested librarians should follow the directions for applications outlined in the October News.

Both of these awards are made possible by the Institute for Scientific Information. The Samuel Lazerow Fellowship for Outstanding Contributions to Acquisitions or Technical Services in an Academic or Research Library honors a senior vice-president of ISI who died in 1981. Lazerow was an honors graduate of Johns Hopkins University and received his MLS from Columbia University. He worked at the Enoch Pratt Free Library and served as the Army's chief library officer in Europe until 1946. In 1947 he became chief of acquisitions at the National Library of Agriculture. In 1952 he took a similar position with the National Library of Medicine and later became chief of the technical services division there. In 1965 he joined the Library of Congress where he headed a task force on the automation and sharing of services between the national libraries. He joined ISI after serving for a quarter century as an administrator with the nation's three national libraries. tured PL/1 Programming for Textual and Library Processing, published by Libraries Unlimited (304 pages, July $1982, \$ 22.50$ ), guides the reader towards a practical and proficient use of the PL/1 programming language as a vehicle for the solution of library and textual processing problems and contains numerous full processing examples. Fosdick, an independent computer consultant in Villa Park, Illinois, is also the author of Computer Basics for Librarians and Information Specialists, published by Information Resources Press (175 pages, 1981, $\$ 17.50)$

- The Library of Congress dedicated on August 5 its new Cataloging Distribution Service DEMAND system - the first computerized system to store images on optical disks and reproduce them in facsimile quality using high-resolution laser printing. Library officials and representatives of Xerox Electro-Optical Systems gathered in the Adams Building to mark the completion of five years of research, development, and testing that led to the system's creation. The Library has issued a request for proposals to optical disk companies so work can begin in using this technology for preservation and storage of materials in its collections. Proposals are also pending for the application of lower resolution

\section{Statement of Ownership and Management}

College \& Research Libraries News is published 11 times a year (monthly, combining July/August), by the American Library Association, 50 E. Huron St., Chicago, Illinois 60611. American Library Association, owner; George M. Eberhart, editor. Secondclass postage paid at Chicago, Illinois. Printed in U.S.A. As a nonprofit organization authorized to mail at special rates (Section 411.3, DMM), the purposes, function, and nonprofit status of this organization, and the exempt status for federal income tax purposes, have not changed during the preceding twelve months.

\section{Extent and Nature of Circulation}

("Average" figures denote the number of copies printed each issue during the preceding twelve months; "Actual" figures denote number of copies of single issue published nearest to filing date-the September 1982 issue.) Total number of copies printed: Average, 13,112; Actual, 13,541. Sales through dealers and carriers, street vendors, and counter sales: not applicable. Mail subscriptions: Average, 10,634; Actual, 9,875. Total paid circulation: Average, 10,634; Actual, 9,875. Free distribution by mail, carrier, or other means, samples, complimentary, and other free copies: Average, 299: Actual, 306. Total distribution: Average, 10,933; Actual, 10,181. Copies not distributed: Office use, left over, unaccounted, spoiled after printing: Average, 2,179; Actual, 3,360. Returns from new's agents: not applicable. Total (sum of previous entries): Average, 13,112; Actual, 13.541.

Statement of Ownership, Management, and Circulation (PS form 3526, July 1981) for 1982 filed with the United States Post Office, Postmaster in Chicago, Illinois, September 15, 1982. 
videodisk technology to the Library's millions of motion pictures, recordings, photos, and other graphic materials. The DEMAND system was developed in response to the Library's need to access and reproduce over 5.5 million master card images in hundreds of different languages that are not in machine-readable form. For many years, catalog cards were stored in a massive warehouse and reproduced using traditional printing methods. With the new system the Library can fill orders for cards in a fraction of the time.

-The University of Illinois Graduate School of Library and Information Science, Urbana, has published the proceedings of the 1981 Clinic on Library Applications of Data Processing, entitled New Information Technologies: New Opportunities (119 pages, August 1982), edited by Linda C. Smith. The papers from the clinic discuss the following topics: microcomputers and word processing technology; data entry and display devices; domestic and foreign projects which are testing markets for videotex and teletex transmission; videodisc technology; telecommunications technology; the changing role of the information professional; database copyright protection; and professional identity and technological change. Copies may be ordered for $\$ 11$ from the University

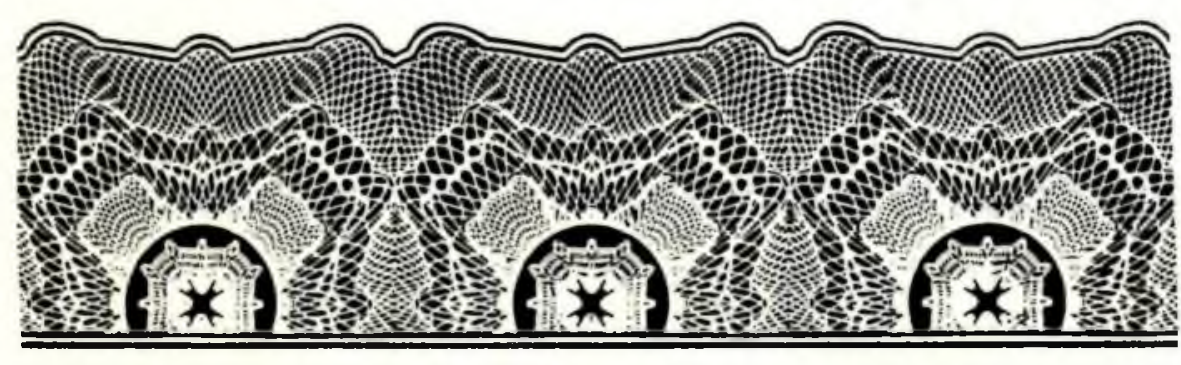

\section{Classified Advertising}

Deadlines: Orders for regular classified advertisements must reach the ACRL office on or before the second of the month preced ing publication of the issue (e.g. September 2 for the October issue). Late job listings will be accepted on a space-available basis after the second of the month.

Rates: Classified advertisements are $\$ 400$ per line for ACRL members, $\$ 5.00$ for others. Late job notices are $\$ 10.00$ per line for members, $\$ 12.00$ for others. Organizations submitting ads will be charged according to their membership status.

Telephone: All telephone orders should be confirmed by a written order mailed to ACRL headquarters as soon as possible. Orders should be accompanied by a typewritten copy of the ad to be used in proofreading. An additional $\$ 10$ will be charged for ads taken over the phone (except late job notices or display ads).

Guidelines: For ads which list an application deadline, that date must be no sooner than the last day of the month in which the notice appears (e.g., October 31 for the October issue). All job announcements should include a salary figure. Job announcements will be edited to exclude discriminatory references. Applicants should be aware that the terms faculty rank and status vary in meaning among institutions.

JOBLINE: Call (312) 944-6795 for late-breaking job ads for academic and research library positions. A pre-recorded summary of positions listed with the service is revised weekly; each Friday a new tape includes all ads received by 1:00 p.m. the previous day. Each listing submitted will be carried on the recording for two weeks. The charge for each two-week listing is $\$ 30$ for ACRL members and $\$ 35$ for non-members.

Fast Job Listing Service: A special newsletter for those actively seeking positions. This service lists job postings received at ACRL headquarters four weeks before they appear in C\&RL News, as well as ads which, because of narrow deadlines, will not appear in C\&RL News. The cost of a six-month subscription is $\$ 10$ for ACRL members and $\$ 15$ for non-members

Contact: Classified Advertising Dep't, ACRL, American Library Association, 50 E. Huron St., Chicago, IL 60611; (312) 944-6780. of Illinois GSLIS, 249 Armory Bldg., 505 East Armory St., Champaign, IL 61820.

- Students at the UNIVERSITY OF WASHINGTON's School of Librarianship can now build databases and experiment with online library management using INMAGIC, data management software developed by Warner-Eddison Associates, an information management and library development company in Cambridge, Massachusetts. INMAGIC was designed for online catalogs in libraries and information centers and has been installed in a variety of research and records centers in business and industry. Educational institutions have also found it valuable, such as a regional educational resource library in Connecticut and a midwestern university where it is used to provide an index for videotape programs. Available for Washington library students are the sample applications for online cataloging, acquisitions, and circulation, and applications for the online managment of library functions. Because the software allows users to design databases and print formats without requiring programming expertise, students can also use it for referral files, course evaluations, and indexing special collections. For further information, contact Warner-Eddison Associates, 186 Alewife Brook Parkway, Cambridge, MA 02138; (617) 661-8124.

\section{FOR SALE}

\section{HARVARD UNIVERSITY LIBRARY DISTRIBUTABLE UNION}

CATALOG, the third edition, is now available. The catalog includes author, title and subject entries for computerized cataloging produced by various Harvard libraries since 1 July 1977. The catalog, which is cumulated every six months, also includes author and title entries for works on order but not yet received and for works received but not yet cataloged. This third edition consists of 475 microfiche (reduction ratio is 48:1). It is available to non-Harvard libraries and interested individuals at a cost of $\$ 110$. Call or write to: Laura Margolis, Harvard University Library, Wadsworth House, Cam. bridge, MA 02138; (617) 495-3650. A free brochure is also available at the same address.

\section{POSITIONS OPEN}

ARCHIVIST, Reference, Robert W. Woodruff Library, Emory University. Responsibilities: Plans, supervises, and participates in reference services for manuscripts, university archives, and rare books. promote use of collections through written communications and verbal presentations. Provide assistance in manuscript processing and collection development, as assigned. Specific duties include implementing and monitoring reference policies and procedures, supervising reading room. training and supervising reference assistants, and disseminating information about collections. Minimum qualifications: ALA-accredited degree; archival training; strong background in history or literature, preferably American; some appropriate public service experience in an archive or manuscript repository desirable: or an equivalent combination of education and experience. Demonstrated strong communications and public relations skills required, as well as ability to work effectively with all segments of academic community and general public. Salary and rank dependent upon qualifications and experience (Librarian I, \$13.500-\$17,500; LibrarIan II. \$16,500-\$23,000). Letter of application, resume, and names of three references to: Herbert $F$. Johnson, Director of Libraries, Robert W. Woodruff Library, Emory University, Atlanta, GA 30322. Application deadline: December 27, 1982. Emory University is an equal-opportunity/affirmative-action employer

ASSISTANT DIRECTOR FOR PUBLIC SERVICES AND COLLECTION DEVELOPMENT. Responsible for the development, evaluation. and budget allocation for the Library's collection and for 